Public service is a means to ensure interaction between
the state and society. The well-being of the population
directly depends on its effective functioning. As you know,
the effectiveness of solving the tasks set is $80 \%$ ensured by
its leaders - civil servants-leaders. It is they who are the
engine of positive changes and the guarantor of the effec-
tiveness of the activities of the entire team. Therefore, in
order to bring the civil service to a qualitatively new level of
efficiency, it is necessary to change the approach to the for-
mation of soft-skills and hard-skills of employees-leaders.
Forthis, it is necessary to introduce a comprehensive system
forthe development of the necessary skills. It is worth, first-
ly, to apply the transfer of the best European technologies.
Secondly, to take into account the realities of the post-in-
dustrial society. Thirdly, to take into account the opinion of
the public. An example of the application of an integrated
approach to the formation of an employee-leader is given.
For this, an analysis of the system of training and advanced
training of civil servants in a developing country, the lead-
ing countries of the European Union, the Organization
for Economic Cooperation and Development - Germany,
France, as well as the nearest country with positive expe-
rience of joining the EU - Poland. The skills and activi-
ties that contribute to the formation of a civil servant-lead-
er both from the point of view of citizens and taking into
account the competencies necessary for effective work are
highlighted. For this, the methods of electronic sociological
survey of public opinion between the ages of 18 and 60 were
used in a sample of 1000 people with an average statistical
dispersion of residence throughout the state and an analysis
ofliterary sources. A system for the formation of an effective
civil servant-leader with the use of technology transfer has
been developed for implementation
Keywords: civil servant, professional development,
training system, employee-leader, hard-skills, soft-skills,
technology, transfer
and

\title{
USE OF THE TRANSFER OF THE BEST EUROPEAN TECHNOLOGIES TO IMPLEMENT THE SYSTEM FOR FORMING OF CIVIL SERVANT-LEADER
}

\section{Introduction}

The functioning of a modern state cannot be imagined without civil service. Usually the civil service consists of legal, organizational, procedural structures and civil servants. It is civil servants who are specially trained to work in this area who ensure the fulfillment of the tasks and functions of the state. It should be noted that in each state this service has its own nuances and is built according to a certain model from specific components. However, in all states, one component in the model is common - people who ensure the effective functioning of the civil service leaders - civil servants-leaders. The level of efficiency of the team's work as a whole will depend on what set of qualities - hard-skills and soft-skills - the leader possesses [1]. This means that the quality of the work of the civil service, and, consequently, the improvement of the standard of living of the population directly depends on the leaders-leaders. Therefore, it is important to determine what set of hard-skills and soft-skills a civil servant-leader should have and develop a set of measures to ensure these qualities.

The best option is not to reinvent the next wheel from a bicycle, but to use the experience of successful countries of the European Union. After all, they have proved the effectiveness of the introduced reforms by the growth of their economies, high standard of living of the population and already have significant developments in the above-mentioned issues. However, it is impossible to completely copy the European model of forming effective civil servants-leaders, because each country has its own characteristics. An algorithm should be used that will highlight the effective tools for each country, based on the historical model of civil service and public expectations.

For clarity, the issue of technology transfer is being considered for the state, on the way to the EU, and is actively modernizing the civil service following the example of leading European countries. The relevance of the research is confirmed by the declared key areas of work of the National Agency for Developing Civil Service for 2021-2023, namely:

- increasing the level of professional competence of civil servants (strategic goal No. 4);

- adaptation of the civil service to EU standards (strategic goal No. 5);

The results obtained will be of direct practical application not only for the developing, but also for other world powers. They can be used to form effective civil servants 
leaders in countries with the same or similar civil service model, actual state of development and historically compiled public expectations.

\section{Literature review and problem statement}

The authors of [2] carried out a detailed comparative analysis of civil service systems in Western Europe and came to the conclusion that in all systems the civil servant-leader should be a leader. It is then, with sufficient opportunities, he will be able not only to efficiently carry out his work, but also to actively introduce innovations. This will help to improve the living standards of the population. The question remained unresolved: what skills a civil servant should have to become a leader and how to contribute to an increase in the effectiveness of a civil servant-leader. The authors of [3] also proved that the maximum effect of a civil servant's activities was achieved when the qualities of a leader are combined with the capabilities of a leader. At the same time, they emphasized the need for the head of a civil servant to be a social leader and defined virtue as an inalienable and obligatory quality. In addition, the issues of coaching in the system of political leadership and Canada's experience in training managerial leaders were discussed in detail. As in the previous work, there was no analysis of the specific components that form an effective leader-civil servant. Only a general description of the qualitative characteristics of the political leadership of the majority and minority in parliament was given, it does not concern public service as such. The author of the work [4] continued and expanded the opinion of the combination of the qualities of a leader with the capabilities of a leader. She emphasized the importance of forming an innovative leader already at the stage of training civil servants. It was shown that the position of a leader-leader in government bodies is a certain social status of an individual. It is he who, giving power, obliges to perform not only official functions, but also imposes certain moral duties and responsibilities. In addition, the author highlighted the main components of the mechanisms of professionalism of future managers and emphasized the importance of the formation of innovative leadership. However, when describing the mechanisms of professionalism, a clear analysis of the skills that are the basis for this was not carried out. The issues of professional socialization of a German civil servant in the learning process were studied in more depth in [5], but the issue of leadership in this context was not considered.

The authors of [6] have identified priority competencies that should be possessed by a civil servant of countries belonging to the Organization for Economic Cooperation and Development (OECD). In addition, they identified the mandatory areas of advanced training and analyzed the necessary percentage of funds for this. Among all funds, the largest percentage (23.5\%) was for training and coaching for leadership, as well as online courses (23\%). However, the distribution of competencies by soft-skills and hard-skills was not carried out, which would make it possible to more accurately determine the necessary areas and methods of advanced training. The authors of [7] identified the elements of the success of German education for civil servants and substantiated the relevance of transferring the idea of dualizing education to partner countries. In addition, the issues of early building to transformation and the introduction of a modulated concept were considered. It is extremely important in the work to describe the transfer of the main ideas and advantages of the German system. However, the issues of leadership and its impact on improving the efficiency of the civil service were considered.

The author of [8] supplemented and classified the types of skills required for a civil service leader. The classification was based on the requirements for the leaders of the civil service of the USA, Great Britain, the Netherlands and Australia. Specifically, technical skills, strategic thinking and communicative action were highlighted. Strategic thinking skills were seen as allowing one to have a vision of the mission and goals of state development, conceptualize individual proposals and ideas into complex programs. Among the skills of communicative action, "emotional intelligence" was singled out, which was responsible for self-awareness, self-regulation, motivation and socialization. Perfect knowledge of the subject and object of activity was classified as technical skills. However, in this work, the author did not offer any mechanism for the development of these skills in civil servants-leaders. The study of soft-skills necessary for an effective civil servant was carried out by the authors of [9]. They conducted their research on the example of Czech civil servants. An interesting conclusion was obtained that the efficiency of work depends on the requirements that are set before the civil servant. It is then, with a lack of what competence, learning new things goes quickly and efficiently. This is especially effective among managers who enjoy attending trainings and online training. However, the issues of combining a leader and a manager in one person and the impact of this option on work efficiency were considered. The influence of hard-skills with the increased efficiency of the work of the civil servant was also considered. Modern methods and tools for developing the necessary leadership skills were considered by the authors of [10]. This is a detailed list of the competencies, skills and techniques that a leader must possess to successfully manage in a world of volatility, uncertainty and ambiguity. The key is learning and reallocating resources. At the same time, it was emphasized that the effectiveness of public administration depends on leaders, and the formation and development of knowledge in this direction require further in-depth study. However, upon a detailed examination of skills and competencies, their division into hard and soft components was not carried out for a clear understanding of the basis for increasing efficiency. Technology transfer as one of the methods of forming an effective civil servant-leader has not been studied. At the same time, the issues of skills transfer for mastering new horizons and creating a better future were considered.

In [11], the issue of leadership in the public service was considered in a broader context, in particular, the experience of the OECD countries was taken into account. Four skills were identified that allow to effectively respond to complex challenges: value-based leadership, open integration, organizational management and network collaboration. Recommendations are given that will help to implement a unified integrated approach to the management of heads of public services in OECD coun- 
tries. However, the paper does not specify how to acquire or develop these skills.

The issue of technology transfer from universities and laboratories was considered in great detail by the author of [12]. At the same time, the topic of technologies was chosen as a multidisciplinary one, and the model was chosen as "conditional efficiency of technology transfer". After the conducted studies, it was concluded that the efficiency of technology transfer depends on the efficiency criteria. They, in turn, depend on a number of factors, including the purpose of technology transfer, the degree of market influence and political efficiency. However, the issue of transfer of public administration technologies was considered. This was started by the author of [13]. In particular, he described the inconsistency of technology transfer in US government. In addition, the author suggested that scientists and practitioners unite around such issues of technology transfer in public administration as: own governance, democratization, equality of society, administrative ability and ethics.

Thus, it is possible to single out the following unresolved components in the direction of increasing the efficiency of civil servants-leaders:

- division of skills necessary for highly efficient work into hard-skills and soft-skills;

- determination of the degree of influence of hard-skills and soft-skills on the level of efficiency of civil servants-leaders;

- implementation of a system for the formation of a civil servant-leader using the transfer of the best European technologies in a developing country.

\section{The aim and objectives of research}

The aim of research is to establish the degree of infusion of hard-skills and soft-skills on the effectiveness of civil servants-leaders and components for the implementation of a system for the formation of civil servants-leaders in a developing state using the transfer of the best European technologies to improve the living standards of the population.

To achieve the aim, the following objectives were set:

- to analyze public opinion and published research results of scientists about the necessary hard-skills and softskills of an effective civil servant-leader;

- to conduct a structural analysis to determine the necessary skills for effective civil servants-leaders;

- to carry out a factor analysis of the influence of European technologies for the formation of civil servants-leaders on the effectiveness of management;

- to analyze the existing system of training and advanced training of civil servants for the implementation of a system for the formation of civil servants-leaders, whose work in a short time will improve the standard of living of the population in modern conditions.

\section{Materials and methods of research}

The research was carried out using general methods of scientific knowledge, in particular dialectical and formal-logical methods: analysis and synthesis, scientific abstraction, generalization, induction and deduction. In particular, polling, comparison, experiment, formalization, axiomatic and special scientific research methods: economic and mathematical, statistical, expert. At the preparatory stage of the study, an analysis of literary sources was carried out. In collecting primary information, we used the method of open observation and study of the relevant legislative documents.

In addition, the method of electronic sociological survey was applied, namely, a questionnaire, in which only closed questions were used. The sample consisted of 1000 people with an average spread of residence throughout the state, is developing. The age of the respondents ranged from 18 to 60 years (from the age of majority to the average statistical retirement age). This approach made it possible to accurately reflect the opinion of the entire public. The main questions were selected by analyzing literature sources on the relevant topic, as well as already conducted public opinion polls. For the convenience of analysis, they were divided into 2 blocks: hard-skills and soft-skills. The first block includes those skills that can be measured and tested, the second - those that are much more difficult to measure. The results were processed in Microsoft Excel 2016, which is included in the licensed office suite Microsoft Office 2016 (USA).

To reasonably determine the necessary skills of effective civil servants-leaders, the method of structural analysis was used, which avoids subjectivity. The object of the structural analysis was selected as a civil servant-leader of the EU countries and a civil servant-leader of a developing one. Data on the required skills were obtained through the analysis of literature sources.

To establish a mutual reference about the influence of European technologies for the formation of civil servants-leaders on the effectiveness of management, the method of multivariate statistics was applied - factor analysis. For this, the Statistica 6.0 software package was used. An integral assessment of the impact of European technologies for the formation of civil servants-leaders on the effectiveness of management was carried out using the following components:

- growth in the well-being of the population;

- improvement of hard-skills and soft-skills of civil servants;

- effectiveness of the work of civil servants.

Table 1 provides a list of the above indicators. Since the gross product is one of the most important indicators of economic development, it can characterize the growth in the well-being of the population in the region. The growth in the number of foreign direct investment and the absence of inflation can be attributed to the factors of growth in the well-being of the population.

As the object of the study, 5 regional state administrations (RSA) in the developing country were selected. It should be noted that the choice was made based on the criterion of starting work on the implemented technology transfer. To formalize the problem statement, we used a linear-standardized factor analysis model with uncorrelated residuals and mutually orthogonal factors:

$$
x_{i}=\sum_{j=1}^{m} I_{i j} \cdot f_{i}+\varepsilon_{i}, i=1, p ; m \leq \mathrm{p},
$$

where $I_{i j}$ - weight of the variable by factor $j$ :

$f_{i}-j$ factor;

$\varepsilon_{i}-$ random variable of the $i$-th variable;

$m$ - the maximum possible number of factors. 
Table 1 opinion of the respondents, is the influence of a particular

The list of indicators of the influence of European technologies for the formation of civil servants-leaders on the effectiveness of management

\begin{tabular}{|c|c|c|}
\hline Constituents & Indicator name & $\begin{array}{c}\text { Indicator } \\
\text { code }\end{array}$ \\
\hline \multirow{4}{*}{$\begin{array}{c}\text { Growth in the } \\
\text { well-being of } \\
\text { the population } \\
\text { in the region }\end{array}$} & $\begin{array}{c}\text { Gross regional product growth } \\
\text { Growth in the number of foreign }\end{array}$ & $X 1$ \\
\cline { 2 - 3 } & $\begin{array}{c}\text { Growth in the number of enterprises } \\
\text { in the region }\end{array}$ & $X 4$ \\
\hline \multirow{2}{*}{$\begin{array}{c}\text { The perfor- } \\
\text { mance of civil } \\
\text { servants }\end{array}$} & $\begin{array}{c}\text { Timely fulfillment of tasks set by } \\
\text { civil servants }\end{array}$ & $X 5$ \\
\cline { 2 - 3 } & $\begin{array}{c}\text { No complaints about the work of } \\
\text { civil servants }\end{array}$ & $X 6$ \\
\hline \multirow{4}{*}{$\begin{array}{c}\text { Improvement } \\
\text { of hard-skills } \\
\text { and soft-skills } \\
\text { of civil ser- } \\
\text { vants }\end{array}$} & $\begin{array}{c}\text { Advanced training or participation } \\
\text { in trainings }\end{array}$ & $X 9$ \\
\cline { 2 - 3 } & Improving communication skills & $X 7$ \\
\cline { 2 - 3 } & $\begin{array}{c}\text { Proficiency in the state language } \\
\text { level not lower than B2 }\end{array}$ & $X 10$ \\
\cline { 2 - 3 } & $\begin{array}{c}\text { Speed and quality of the decision of } \\
\text { the set tasks }\end{array}$ & $X 11$ \\
\cline { 2 - 3 } & adaptability & $X 13$ \\
\hline
\end{tabular}

During the research, the estimation of the elements of the covariance matrix $\sum x_{i}$, which were obtained by observing the indicators, was calculated. The structural parameters of the model - the elements $I_{i j}$ and the variance of the remainders $\varepsilon_{i}$ are unknown and require determination. For the RSAs analyzed, 3 factors were selected that explain at least $71.534 \%$ of the cumulative percentage of variance. In the analysis of factor load the degree of influence of indicators will be established: to 0.5 - weak influence, from 0.5 to 0.7 - average, more than 0.7 - strong influence.

\section{Research results of the degree of influence of} hard-skills and soft-skills on the effectiveness of civil servants-leaders and components for the implementation of a system for the formation of civil servants-leaders

5. 1. Research results of the necessary hard-skills and soft-skills of an effective civil servant-leader

The results of a study of the country's public opinion regarding the necessary hard-skills and soft-skills for an effective civil servant-leader are shown in Fig. 1, $a, b$. Each column shows the need for a certain component of hard-skills or softskills (according to respondents aged 18 to 60 ) for the effective work of a civil servant-leader. With the help of these graphs, you can highlight the main necessary components of the skills.

Fig. 2 shows the diagrams of the importance of hardskills and soft-skills of an effective civil servant-leader, which was compiled by the authors based on the results of a survey of respondents aged 18 to 60 years. The cumulative total importance of all skills is $100 \%$. Each sector has a designated percentage that shows how significant, in the skill on the overall effectiveness of a civil servant-leader. Fig. 3 summarizes the results of the study of the significance of hard-skills and soft-skills of an effective civil servant-leader, which was compiled based on the results of the analysis of the OECD reporting. The cumulative total importance of all skills is $100 \%$. Each sector has a designated percentage that shows how significant, according to the results of OECD reporting, is the impact of a particular skill on the overall performance of a civil servant-leader. This analysis makes it possible to refine the preliminary results, as it establishes the degree of importance of each skill.

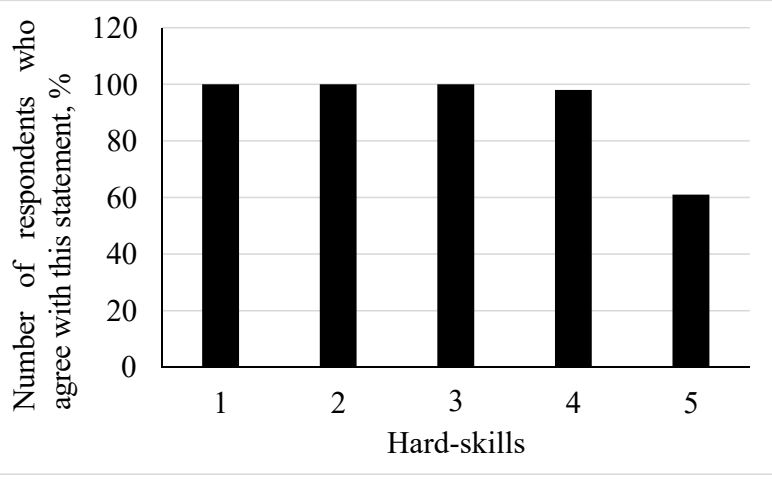

$a$

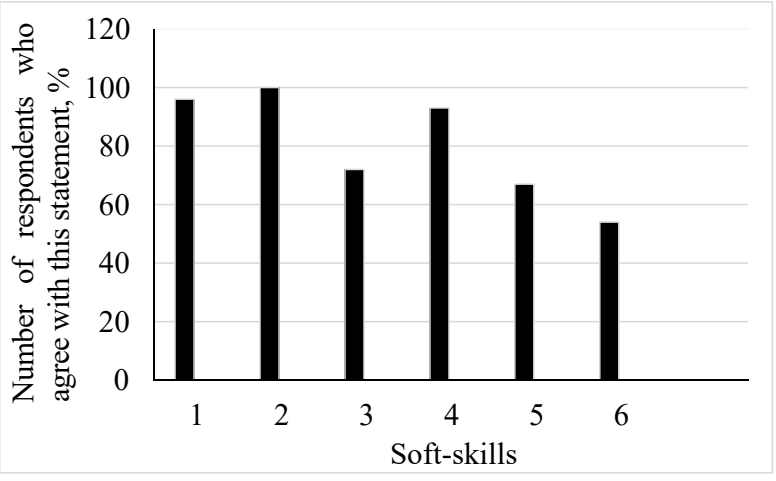

$b$

Fig. 1. Results of the survey of respondents on the set: hard-skills and soft-skills: $a$ - the results of the survey of respondents on the set of hard-skills:

1 - a specialist in his/her field, 2 - constantly improves his/her professional level, 3 - has an appropriate level of education, 4 - fluent in the state language, 5 - speaks a foreign language at the B2 level; $b$ - results of a survey of respondents on the set of soft-skills: 1 - quickly and efficiently solves the assigned tasks, 2 - honestly, not corrupt, 3 - patriot, 4 - non-conflict, balanced, 5 - inspires confidence, 6 - politically impartial

It should be noted that in the pie chart, skills are ranked in ascending order of their impact on the performance of a civil servant-leader. However, this does not mean that, for example, a civil servant should not be able to process information. According to the methodology used, this means that this skill must necessarily be present in the set of skills, but the level of effectiveness is less affected. 


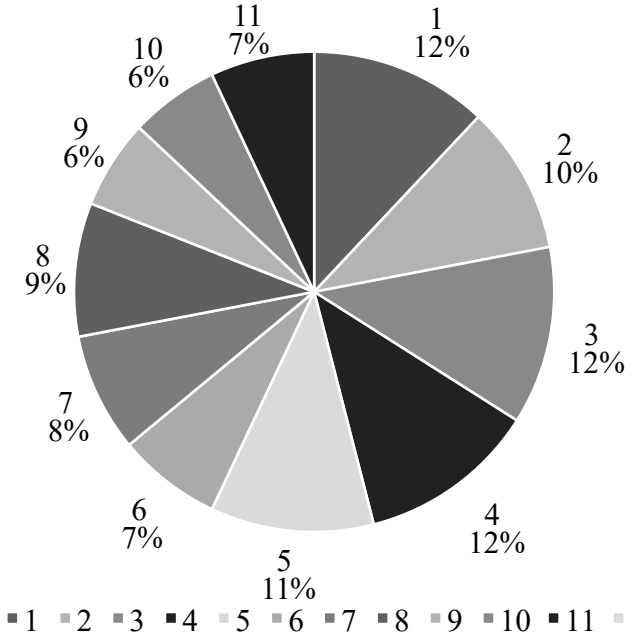

Fig. 2. Diagram of the importance of hard-skills and soft-skills of a civil servant-leader of the XXI century:

1 - a specialist in his/her field; 2 - constantly improves his/her professional level; 3 - has an appropriate level of education; 4 - fluent in the state language; 5 - speaks a foreign language at the B2 level; 6 - quickly and efficiently solves assigned tasks; 7 - honest, not corrupt;

8 - patriot; 9 - non-conflict, balanced; 10 - credible; 11 - politically impartial

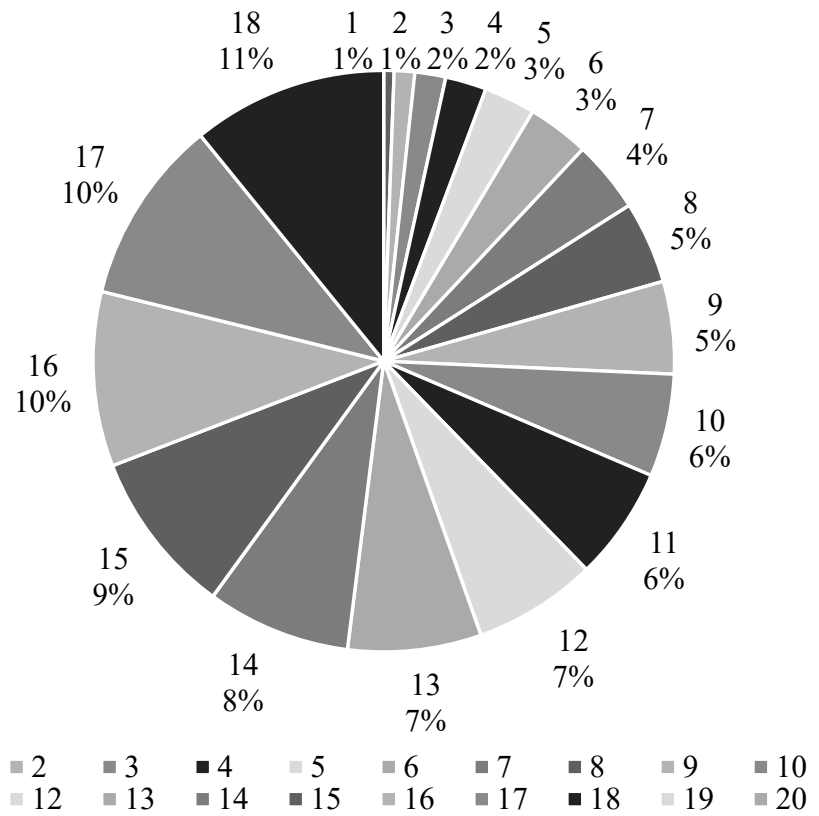

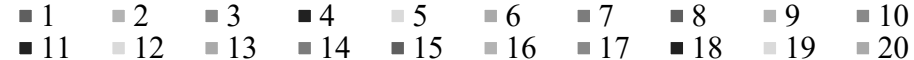

Fig. 3. Diagram of the importance of hard-skills and soft-skills of a civil servant-leader of the XXI century: 1 - ability to process information; 2 - responsibility; 3 - diplomacy; 4 - innovativeness;

5 - organizational skills; 6 - loyalty; 7 - adaptability; 8 - customer focus; 9 - initiative; 10 - learning, self-development;

11 - interpersonal relationships; 12 - professionalism; 13 - building for teamwork; 14 - communication; 15 - strategic thinking; 16 - efficiency; 17 - leadership; 18 - values and ethics. Compiled by the authors based on the results of the analysis of the OECD reporting [6]

5. 2. Results of the structural analysis to determine the necessary skills for effective civil servants-leaders

Tables 2, 3 presents the results of a structural analysis to determine the necessary soft-skills and hard-skills of effective civil servants-leaders of the EU and developing countries.
Table 2

The results of structural analysis to determine the required soft-skills for effective civil servants-leaders of the EU countries and the developing

\begin{tabular}{|c|c|}
\hline $\begin{array}{c}\text { Soft skills of effective civil ser- } \\
\text { vants-leaders of the EU countries }\end{array}$ & $\begin{array}{c}\text { Soft-skills of effective } \\
\text { civil servants-leaders of the } \\
\text { developing }\end{array}$ \\
\hline Ability to take responsibility & Charisma \\
\hline Strategic thinking & $\begin{array}{c}\text { Meeting expectations } \\
\text { (honesty, impartiality, } \\
\text { efficiency) }\end{array}$ \\
\hline Self-management & Self-management \\
\hline Initiative and creativity & $\begin{array}{c}\text { Speed and creativity in } \\
\text { solving problems }\end{array}$ \\
\hline Communicativeness & Non-conflict \\
\hline Ethical values & Patriotism \\
\hline
\end{tabular}

Table 3

Results of structural analysis to determine the required hard-skills of effective civil servants-leaders of the EU and developing countries

\begin{tabular}{|c|c|}
\hline $\begin{array}{c}\text { Hard-skills of effective civil } \\
\text { servants-leaders of the EU } \\
\text { countries }\end{array}$ & $\begin{array}{c}\text { Hard-skills of effective civil } \\
\text { servants-leaders of the devel- } \\
\text { oping country }\end{array}$ \\
\hline Quality education & Quality education \\
\hline Professionalism & Professionalism \\
\hline $\begin{array}{c}\text { Ability for learning and } \\
\text { self-development }\end{array}$ & $\begin{array}{c}\text { Ability for learning and } \\
\text { self-development }\end{array}$ \\
\hline
\end{tabular}

In fact, it is possible to note the complete coincidence of the necessary hard-skills of effective civil servants-leaders of the EU and developing countries.

5. 3. Results of factor analysis of the influence of European technologies for the formation of civil servants-leaders on the management effectiveness

Table 4 shows the results of factor analysis for the developing regional state administration. The results of calculating the corresponding factorial loads, which were obtained by the method described above. difficult to interpret, this is how the rotation procedure was applied. The results are presented in Table 5 After that, indicators were chosen, the values of which to a greater extent characterize the influence of European technologies for the formation of civil servants-leaders on the effectiveness of management in the Regional State Administration. The results are shown in Table 6 . Moreover, one plus marked the average impact (from 0.5 to 0.7 ), and two pluses, a strong influence (more than 0.7$)$.

Table 4

The results of factor analysis for the regional state administration of the developing countries

\begin{tabular}{|c|c|c|c|}
\hline No. of factor & $\begin{array}{c}\text { Factor eigen- } \\
\text { value }\end{array}$ & $\begin{array}{c}\text { Percentage } \\
\text { of total factor } \\
\text { variance, \% }\end{array}$ & $\begin{array}{c}\text { Accumulated } \\
\text { variance of } \\
\text { factors, \% }\end{array}$ \\
\hline 1 & 7.3455 & 32.432 & 37.435 \\
\hline 2 & 1.6123 & 8.9568 & 71.534 \\
\hline 3 & 3.4537 & 15.5632 & 42.789 \\
\hline
\end{tabular}


Table 5 Intensity of factorial loads for RSA of developing country after the rotation procedure

\begin{tabular}{|c|c|c|c|}
\hline \multirow{2}{*}{ Indicator code } & \multicolumn{3}{|c|}{ The value of factor loads } \\
\cline { 2 - 4 } & Factor 1 & Factor 2 & Factor 3 \\
\hline$X 1$ & 0.843081 & 0.00644361 & -0.013519 \\
\hline$X 2$ & 0.661918 & -0.0812378 & -0.370516 \\
\hline$X 3$ & 0.145373 & 0.237593 & 0.161933 \\
\hline$X 4$ & 0.754852 & -0.15467 & 0.020056 \\
\hline$X 5$ & -0.02889 & -0.032675 & 0.687513 \\
\hline$X 6$ & 0.596754 & 0.643258 & -0.065432 \\
\hline$X 7$ & -0.215983 & 0.570034 & 0.176929 \\
\hline$X 8$ & 0.103975 & 0.123654 & 0.843567 \\
\hline$X 9$ & 0.718765 & 0.122456 & 0.183016 \\
\hline$X 10$ & 0.014567 & 0.345671 & 0.823581 \\
\hline$X 11$ & -0.193451 & 0.215673 & 0.745672 \\
\hline$X 12$ & -0.124562 & 0.536782 & -0.23789 \\
\hline$X 13$ & -0.17564 & 0.645615 & 0.315535 \\
\hline
\end{tabular}

Table 6

Entry of indicators to factors for RSA

\begin{tabular}{|c|c|c|c|}
\hline \multirow{2}{*}{ Indicator code } & \multicolumn{3}{|c|}{ The value of factor loads } \\
\cline { 2 - 4 } & Factor 1 & Factor 2 & Factor 3 \\
\hline Gross regional product growth & ++ & & \\
\hline $\begin{array}{c}\text { Growing foreign direct investment } \\
\text { in the region }\end{array}$ & + & & \\
\hline No inflation & & - & \\
\hline $\begin{array}{c}\text { Growing number of enterprises in } \\
\text { the region }\end{array}$ & ++ & & \\
\hline $\begin{array}{c}\text { Timely fulfillment of tasks set by } \\
\text { civil servants }\end{array}$ & & & + \\
\hline $\begin{array}{c}\text { No complaints about the work of } \\
\text { civil servants }\end{array}$ & & + & \\
\hline Improving communication skills & & + & \\
\hline Improving self-management skills & & & ++ \\
\hline $\begin{array}{c}\text { Advanced training or participa- } \\
\text { tion in trainings }\end{array}$ & & & ++ \\
\hline Fluency in the state language & & & ++ \\
\hline $\begin{array}{c}\text { Proficiency in a foreign language } \\
\text { at a level not lower than B2 }\end{array}$ & & & ++ \\
\hline Speed and quality of solving tasks & & & + \\
\hline Adaptability & & + & \\
\hline
\end{tabular}

It should be noted that in Table 7, the "++" sign denotes a strong influence, and a "+" sign - an average influence, and a "+" sign - a weak influence, and a "-" sign - the absence of the influence of factors.

5. 4. Research results of the training system for the development of stages of implementation of technology transfer

In accordance with the Regulations on the system of vocational training for civil servants, heads of local state administrations, their first deputies and deputies, officials of local government and local councils, in a developing state, there is a system of vocational training [12]. It is based on principles that make it possible to effectively and ahead of the challenge of the modern post-industrial society, namely:

- compulsory - training is compulsory for everyone, without exception;
- continuity - learning throughout life;

- purposefulness, predictability and practicality - training that provides the need for knowledge that will really be in demand;

- individualization - training according to an individual approach to each person, which is much more effective than the use of universal teaching methods;

- openness and virtue - training that does not allow the use of any dishonest ways in assessing its results;

- proximity to the place of residence - training that provides maximum convenience;

- guaranteed funding - training is carried out at the expense of the state, which should be included in the local budget [12].

According to the Transfer, in a developing country, professional training of civil servants is carried out through the system of educational institutions, institutions, organizations, regardless of the form of ownership. In this case, the types of vocational training are:

- preparation for master's programs - the acquisition of new knowledge by participants that correspond to the educational programs approved by the Ministry of Education and Science;

- advanced training - the acquisition of new and/or improvement of previously acquired competencies by participants in vocational training within the framework of professional activity or field of knowledge;

- internship - the acquisition of practical experience by participants in vocational training in performing tasks and responsibilities in a professional activity or field of knowledge;

- self-education - self-organizing acquisition by participants of vocational training of certain competencies, in particular in everyday activities related to professional, social or other activities, leisure.

The scope of educational programs for preparation is as follows:

- educational and professional training programs for masters in the specialty "Public administration and administration" for training masters in the specialty "Public administration and administration" - 90 ECTS credits;

- general and special professional (certificate) programs - at least 2 ECTS credits;

- general and special short-term professional development programs - not less than 0.2 ECTS credits ( 6 hours) and not more than 1 ECTS credit.

The form of study is full-time, distance and mixed. When using a blended form of education, according to legislative documents, the number of hours for distance learning varies from 30 to $70 \%$. Requirements for the content and structure of advanced training programs were approved. Transfer by order No. 185-19 dated 10.10.19.

Planning for professional development of management personnel is important for both the individual and organizational development of the authorities in which they work [14]. The need for professional training of a civil servant is determined by his immediate supervisor and the personnel management service of the state body based on the results of performance assessment. At the same time, they use the methodology developed by the National Agency for Civil Service (approved by order of October 15, 2019 No. 188-19). In total, during one calendar year, civil servants have to collect at least 1 ECTS credit (30 hours) used to implement individual programs. 
To develop a system for the formation of an effective public service leader using technology transfer, an analysis of the existing training system was carried out - advanced training of civil servants in the leading EU and OECD countries. The results are presented in Table 7 .
It should be noted that European state institutions determine not only the need to develop leadership potential, but also their responsibility for creating the necessary conditions for its development. Each country defines its own approach to developing the ability of leaders.

Table 7

Summarizing results of the analysis of professional development of civil servants in Germany, France and Poland

\begin{tabular}{|c|c|c|c|}
\hline Name & Germany & France & Poland \\
\hline $\begin{array}{c}\text { Types } \\
\text { and } \\
\text { duration } \\
\text { of pro- } \\
\text { fessional } \\
\text { develop- } \\
\text { ment }\end{array}$ & $\begin{array}{l}\text { Course or thematic train- } \\
\text { ing, Self-study programs, } \\
\text { preparatory service. } \\
\text { The lower-level prepa- } \\
\text { ratory service lasts six } \\
\text { months, and the proba- } \\
\text { tionary period is one year. } \\
\text { The highest level pre- } \\
\text { paratory service lasts at } \\
\text { least three years. After } \\
\text { successfully passing the } \\
\text { exam, the civil servant } \\
\text { undergoes a probationary } \\
\text { period of two and a half } \\
\text { years }\end{array}$ & $\begin{array}{c}\text { Refresher courses; training; } \\
\text { vocational training for tem- } \\
\text { porary dismissal from public } \\
\text { service in reserve or with } \\
\text { the provision of leave for } \\
\text { socially significant scientific } \\
\text { developments }\end{array}$ & $\begin{array}{l}\text { Distance learning, courses, } \\
\text { internships abroad. There is a } \\
\text { program to exchange experiences } \\
\text { with institutions overseeing } \\
\text { civil servants in a number of } \\
\text { countries. } \\
\text { The preparatory service for new } \\
\text { employees is also mandatory, } \\
\text { which, however, can be canceled } \\
\text { by the decision of the employer } \\
\text { (administration) in individual } \\
\text { cases. Preparatory service can } \\
\text { last up to four months }\end{array}$ \\
\hline Pays & $\begin{array}{c}\text { Compulsory programs - } \\
\text { by government order, } \\
\text { independent study - paid } \\
\text { by a civil servant }\end{array}$ & $\begin{array}{c}\text { Civil servants spend noth- } \\
\text { ing on training and receive } \\
\text { monetary compensation for } \\
\text { expenses and relocation. } \\
\text { Funding for various train- } \\
\text { ing activities is provided by } \\
\text { ministries. } \\
\text { Additional professional } \\
\text { education is carried out by } \\
\text { civil servants independently }\end{array}$ & $\begin{array}{l}\text { Paid by public funds, self- } \\
\text { study - paid by a civil servant }\end{array}$ \\
\hline Choose & $\begin{array}{l}\text { Compulsory subjects are } \\
\text { studied in specialized edu- } \\
\text { cational institutions from } \\
\text { the State Administration, } \\
\text { optional subjects are } \\
\text { studied by public officials } \\
\text { independently }\end{array}$ & $\begin{array}{c}\text { Compulsory subjects are } \\
\text { studied in specialized edu- } \\
\text { cational institutions of pub- } \\
\text { lic administration, optional } \\
\text { subjects are studied by civil } \\
\text { servants independently }\end{array}$ & $\begin{array}{l}\text { All officials, except for those } \\
\text { in high positions, are supposed } \\
\text { to have individual profession- } \\
\text { al development plans. In the } \\
\text { program, the civil servant in- } \\
\text { dicates what skills he is trying } \\
\text { to develop, what knowledge } \\
\text { to get, when and how he is } \\
\text { going to do it. On the basis of } \\
\text { this plan, the official is sent } \\
\text { to the courses. The immediate } \\
\text { superiors approve the plan and } \\
\text { control its implementation }\end{array}$ \\
\hline $\begin{array}{l}\text { Period- } \\
\text { icity }\end{array}$ & $\begin{array}{c}\text { The conditions for vo- } \\
\text { cational training of civil } \\
\text { servants are prescribed } \\
\text { in the annual collective } \\
\text { agreement. After passing } \\
\text { the probationary period, } \\
\text { on your own application } \\
\text { or as needed. } \\
\text { Civil servants who are } \\
\text { just enrolled in the civil } \\
\text { service must undergo } \\
\text { training for } 6-8 \text { weeks. } \\
\text { In the lower job groups, } \\
\text { when the rating is } \\
\text { "good", the promotion is } \\
\text { carried out after } 6 \text { years, } \\
\text { and when the rating is } \\
\text { "quite satisfactory"- } \\
\text { after } 8 \text { years }\end{array}$ & \begin{tabular}{|} 
The title is practically the \\
property of a civil servant. \\
Civil servants cannot be \\
fired (unless disciplinary vi- \\
olations or low performance \\
levels are found). The title \\
gives a civil servant the \\
opportunity to engage in \\
work that corresponds to \\
the level and qualifications \\
of the corresponding title. \\
But the work itself can be \\
entrusted to a civil servant \\
or withdrawn in accordance \\
with the needs of the civil \\
service. This allows the civil \\
servant to do a certain job \\
while that job is in demand
\end{tabular} & $\begin{array}{l}\text { Attestation - once every } \\
2 \text { years, a civil servant can } \\
\text { receive a high rank after } \\
\text { receiving a positive assessment } \\
\text { of his work, then - compulsory } \\
\text { advanced training, which is } \\
\text { planned, organized and super- } \\
\text { vised by the inequality, respond- } \\
\text { ing to the educational needs of } \\
\text { the office itself (each member of } \\
\text { the Civil Service Corps has an } \\
\text { individual program professional } \\
\text { development) }\end{array}$ \\
\hline
\end{tabular}

6. Discussion of research results

6. 1. Discussion of the research results of hard-skills and soft-skills of an effective civil servant-leader

As can be seen from the survey results presented in Fig. 1, a, an effective civil servant-leader must first of all have a certain set of hard-skills, namely the appropriate level of education and be ready for continuous learning. In particular, $100 \%$ of respondents from the developing country expressed their agreement with this statement. These results are explained by the change in the mentality of the post-industrial society and the understanding that "Knowledge is power" that ensures future well-being. Since the English language is generally recognized in the EU, it is necessary to speak it at the B2 level. It is quite sufficient to ensure understanding and communication in a pro-process environment and, with the right approach to organizing training, can be mastered in 2 years, provided that there are specialized methodically developed courses for these purposes. However, only $61 \%$ of respondents agree with this statement. This can be explained by the historically established difficulties in the study of a foreign language and its relation to the group of Germanic languages, semantically different from the developing language group. It should be noted that according to the Civil Service Law, all category A civil servants must be fluent in English, as it is the main language of the Council of Europe. However, bill 2544 is under consideration, which aims to exclude this requirement to ensure the equal right of citizens to access the civil service [15].

It follows from the survey that an effective civil servant-leader definitely needs to be fluent in the state language (Fig. 1,a). It should be noted that when conducting a survey in the state, there 
is a shortage of $2 \%$ in terms of the level of proficiency in the state language obtained at the expense of residents of the East and Center, however, compared with $98 \%$ of the majority, it is insignificant. It is extremely important for a civil servant-leader to constantly improve his professional level, because this is one of the main conditions for moving up the career ladder. According to the survey, the importance of this component is recognized by $71 \%$ of the respondents, while a civil servant must be a specialist in his field (100\% of respondents agree), effectively and quickly solve the assigned tasks (96\% of respondents) (Fig. 1,b). It should be noted that patriotism is classified as soft-skills, since it is something that is brought up from birth or acquired in the process of life is not measured in quantitative indicators, but is very clearly described qualitatively.

At the same time, the distribution of the components of soft-skills and hard-skills in the general set of skills is not equivalent. In particular, the respondents named the most important components in terms of importance: the appropriate level of education, professionalism in their field and fluency in the state language (Fig. 2). All of these criteria, according to the survey, received roughly equal numbers of votes, which together account for $46 \%$ of the overall assessment of the importance of skills and 10 to $12 \%$ separately. Scored $1 \%$ less proficiency in a foreign language at the B2 level (11\%) and $2 \%$ less - patriotism (9\%). After them, in terms of importance - honesty and non-corruption (8\%). Political impartiality and speed of solving problems $-7 \%$, non-conflict, prudence and ability to inspire confidence $6 \%$. Thus, it can be generalized that according to the public opinion, the most important for a civil servant-leader is hard-skills. The set of required soft-skills is important, but they are not decisive.

If we compare these results with the generalized results from the OECD report (Fig. 3), it turns out that joint hardskills are the ability to learn and competence in their field. In particular, this can be clearly seen if we combine the following skills into a learning ability (that is, the ability to apply the principle of "learning throughout life"):

- training, self-development (6\%) - hard-skills;

- initiative (5\%) - soft-skills;

- the ability to process information (1\%) - hard-skills;

- communication (8\%) - soft-skills;

- organizational skills (3\%) - soft skills.

According to the results of the analysis of the OECD reporting, professionalism (7\%) - hard skills is responsible for competence in the field (Fig. 3). With soft-skills - values and ethics (11\%), which, by the way, according to the OECD report, together with leadership skills (10\%) and efficiency $(10 \%)$, occupy key positions among all the necessary skills for a civil servant-leader. On a scale of importance, skills are essential, but least important are the ability to process information and accountability (1\%). Thus, it is clearly seen that in the OECD countries the necessary set of soft-skills is extremely important for the effective work of a leading official. In developing countries, hard skills are preferred.

6. 2. Discussion of the results of the structural analysis to determine the necessary skills of effective civil servants-leaders

Based on the results of a structural analysis of the softskills of an effective civil servant of a developing leader (Table 2), it was found that the necessary skills are:
- self-management;

- initiative and creativity;

- ethical values.

Thanks to the skills of self-management, the civil servant-leader of the developing one will be able not only to effectively and timely solve the assigned tasks, but also to communicate with the team in a highly productive manner. This will increase their overall performance by an order of magnitude. Initiative and creativity will provide the generation of new ideas, which is extremely necessary for public service at the stage of the childhood life cycle. It should be noted that it is at this stage that the public services of developing countries are located. In addition, these skills will enable new approaches and innovative methodologies to be developed to meet current challenges. Ethical values will ensure mutual understanding between civil servants and developing residents and, of course, will greatly simplify communication with colleagues. It is they who will protect civil servants from the emergence of conflict situations, which, of course, will have a positive effect on the efficiency of work in general.

According to the results of a structural analysis of the hard-skills of an effective civil servant of a developing leader (Table 3), it was found that the necessary skills are:

- quality education;

- professionalism;

- ability for self-development.

A quality education will create the basis for the further development of professional skills. Professionalism will ensure efficiency in work, and the ability for self-development - the implementation of the principle of "learning throughout life".

6. 3. Discussion of the results of factor analysis of the influence of European technologies for the formation of civil servants-leaders on the effectiveness of management

For the RSA, which were analyzed, the first factor has the greatest significance of the influence of European technologies for the formation of civil servants-leaders on the effectiveness of management. Its variance is $32.4 \%$ of the total variance. When analyzing the composition of the factor, it was found that the most significant influence on factor loads has:

$-X 1$ - growth of the gross regional product;

- X4 - growth in the number of enterprises in the region.

Based on this, this factor can be interpreted as a factor in improving the well-being of the population. The second factor ranks third in importance and accounts for $8.96 \%$ of the total variance. When analyzing the composition of the factor, it was found that the most significant influence on factor loads has:

$-X 6$ - no complaints about the work of the state services;

- X7 - improving communication skills;

$-X 12$ - speed and quality of solving the assigned tasks;

- X13 - adaptability.

Based on the above, this factor can be interpreted as a communication or interaction factor (soft-skills). The third most important factor ranks second in terms of the percentage of total factor variance $(15.57 \%)$. When analyzing the composition of the factor, it was found that the most significant influence on factor loads has:

$-X 5$ - timely fulfillment of assigned tasks by civil servants; 
- X8 - improvement of self-management skills;

- X9 - advanced training or participation in trainings;

- X10 - fluency in the state language;

$-X 11-$ proficiency in a foreign language at a level not lower than B2.

Based on this, this factor can be interpreted as an efficiency factor (hard-skills).

\section{4. Discussion of the research results of the existing system of training and advanced training}

It should be noted that in OECD countries, approaches to professional development have one common feature - the creation of special institutions or the introduction of special training programs for managers, and first of all for senior executives [11]. This greatly contributes to improving the efficiency of not only the heads of the relevant government services, but also improves the efficiency of all employees of departments. At the same time, scientists note that recommendations regarding modern approaches to leadership cannot be considered constant, but should be improved in practice until a certain level of competence is reached. Therefore, in Germany, France and Poland, the principle of "learning throughout life" is applied, which clearly proves its effectiveness. Regular and successful completion of professional development of civil servants in OECD countries provides them with the right to further work, the establishment of appropriate allowances and bonuses, and opens up opportunities for career advancement.

The French system of professional development of management personnel is one of the most developed in Europe. The advantages of the system of professional development of civil servants in France include versatility. In particular, a balanced understanding of the tasks, decentralization and territorial organization of public services is constantly maintained. Communication skills are deepened in a separate direction. Develop an understanding of the need for cooperation with institutions of the European Community. Much attention is paid to the quality of human resource management and a focus on green innovation.

However, it should be noted that one of the main disadvantages of all studied systems is the low level of mobility. It is compensated by a high social status and a clear mechanism of progressive wages.

Summarizing the results obtained, it can be argued that the formation of a civil servant-leader, both from the point of view of citizens and taking into account the competencies necessary for effective work, is facilitated by constant self-development. Among the complex of measures necessary for this, it is especially necessary to highlight the deepening and acquisition of new knowledge, as well as the improvement of communication skills and emotional intelligence.

The peculiarities of the proposed method consist in a combination of studies of the actual opinion of the public of the state, in which it is proposed to implement the transfer of technologies with analytical processing of the best European practices. Thus, the maximum effect and the combination of science and practice are achieved.

Limitations that were inherent in the conducted research:

- territorial effect;

- comparable to the number of residents in the sample.

The error that can be caused by these restrictions is leveled out due to the uniform age and territorial dispersion among the respondents. In the future, for maximum accura- cy of the results obtained, it will be possible to conduct an electronic sociological survey using the same questionnaire of residents of OECD countries with the same sample. This will greatly simplify the interpretation of the results, and the error will be minimal. In addition, it is desirable to expand the range of issues and classify them into 4 blocks, which will relate to: leadership based on values, open integration, organizational management and network collaboration. Difficulties that may be encountered at this stage are technological difficulties in organizing the survey, since the respondents are citizens of other states. The way to eliminate these difficulties is to obtain an EU grant and, accordingly, information support for research or cooperation with scientists - citizens of OECD countries.

Considering all of the above, using the method of transferring the best European technologies and taking into account the developments published in [16], for the implementation of the system for the formation of a civil servant-leader, the following steps must be observed (Fig. 4):

1. Quality basic training.

2. Obtaining a certificate of proficiency in a foreign language at a level not lower than B2 and confirmation of proficiency in the state language.

3. Advanced training within the state at least once a year in "network universities". At the same time, universities that have passed competitive selection, have a highly qualified teaching staff and scientific and methodological support should act as network universities. The topic of advanced training should be determined by the civil servant and agreed with the immediate supervisor. Form of study - fulltime and distance learning in a ratio of 30 to 70 . Volume - at least 2 ECTS credits per year.

4. Mandatory advanced training abroad in the leading EU countries at least once every 3 years. Volume - not less than 1 ECTS credit.

5. Implementation of the principle of "lifelong learning".

6. Development of emotional intelligence.

It should be noted that payment for the training of a civil servant should be fully funded from the state budget, and in case of successful completion of all stages, a salary increase of $25 \%$ should be established. This approach will greatly stimulate civil servants to develop. He will form a cohort of civil servants, leaders in European management experience, which will undoubtedly significantly accelerate the progress of the state in the EU and bring civil service to a new quality level. In addition, it will ensure a rapid improvement in the standard of living of the population, because the effective work of civil servants significantly affects the success of the implementation of reforms, the main goal of which is to bring the state to a qualitatively new - European level.

It is possible to quantify the effect of the introduction of the transfer of European technologies in a developing public service by assessing the dynamics of changes in GDP per capita. Fig. 5 shows the change in the dynamics of GDP per capita in the OECD countries, from which technology transfer will be carried out. As can be seen from Fig. 5, Poland demonstrates the best results of changes in GDP per capita. Even in the years of the pandemic did not begin to fall. This means that not only the correct policy is being implemented in the country, but also the civil service works well and smoothly. In France and Germany, a slightly worse result is observed. The decline in GDP is higher compared to 2018, but less than in a developing country (Ukraine). 


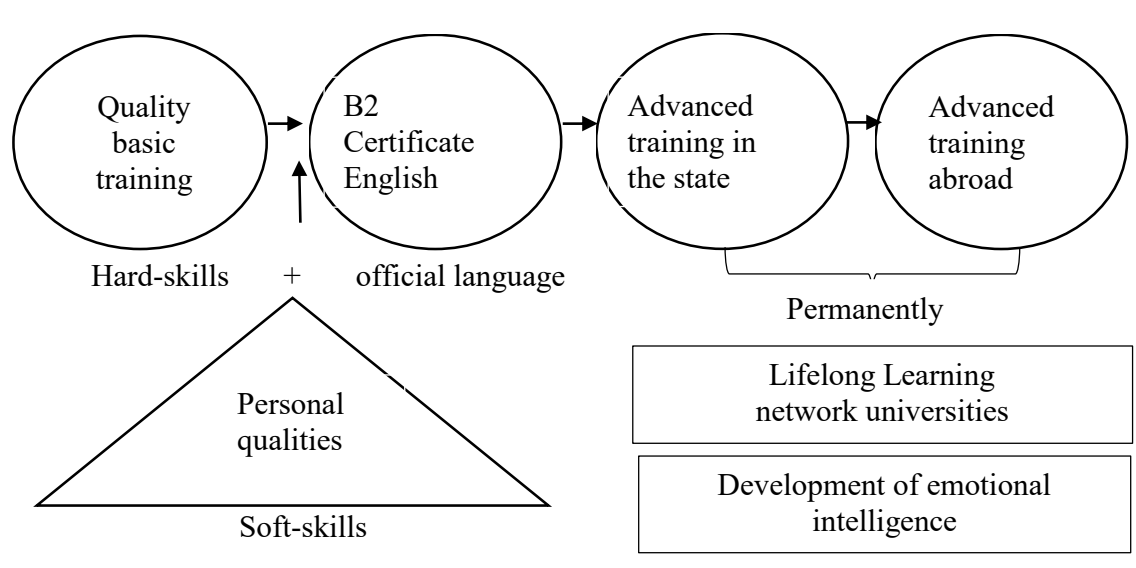

Fig. 4. The system of forming an effective civil servant-leader using the method of transferring the best European technologies

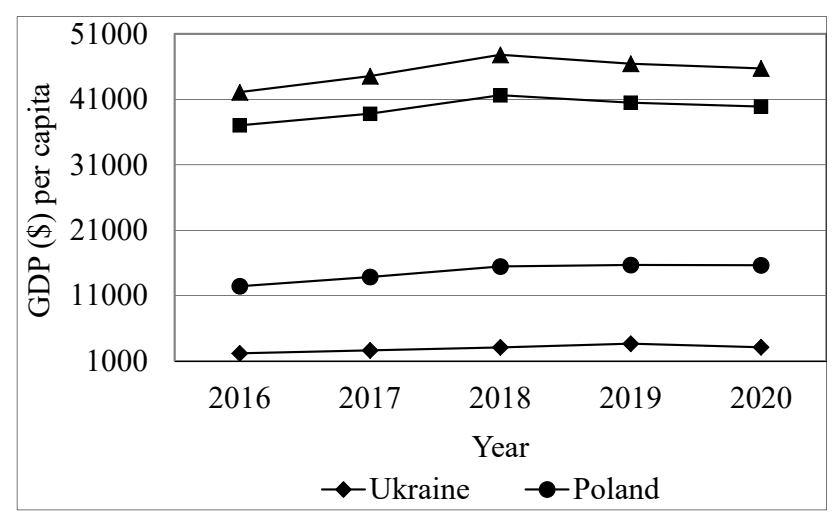

Fig. 5. Dynamics of changes in GDP per capita in a developing country and OECD countries in 2016-2020

Since all the countries shown in Fig. 5, suffered large economic losses due to the pandemic since 2019, it is impossible to realistically assess the effectiveness of the civil service. However, it is safe to say that the technologies of forming an effective civil servant-leader must be introduced in a developing country. This confirms GDP per capita growth in OECD countries until 2018 (Fig. 5).

\section{Conclusions}

1. For effective work of civil servants-leaders there are the necessary high skills of hard-skills (professional knowledge, proficiency at a high level of the state and foreign languages). In the OECD countries, for the effective work of civil servants-leaders there are the necessary high soft-skills (emotional intelligence, communication skills), as well as the desire to learn throughout life.

2. The set of skills of an effective state leader of the country has been established. In particular, the required soft-skills are:

- self-management;

- initiative and creativity;

- ethical values.

The required hard skills are:

- quality basic education;

- professionalism;

- ability for self-development.

3. It has been established that the influence of European technologies for the formation of civil servants-leaders on the effectiveness of management is reflected in the level of well-being of the population, as well as on the efficiency of the work of civil servants-leaders.

4. The components for the implementation of the system of formation of civil servants-leaders in the state have been established, the following is developing:

- high-quality basic training;

- fluency in the state language;

- B2 level proficiency in English;

- systematic professional development;

- introduction of the principle of "learning throughout life";

- development of emotional intelligence.

- use of "network universities".

It is proposed to carry out a quantitative assessment of the efficiency of technology transfer through a detailed study of the dynamics of changes in GDP per capita.

\section{References}

1. Abdul, R. A., Garoot, S. E., Ahmad, N. B., Hasim, R., Tariq, Z. (2011). Servant Leadership's Values and Staff's Commitment: Policy Implementation Focus. American Journal of Scientific Research, 13, 18-40. Available at: https://core.ac.uk/download/ pdf/300366172.pdf

2. Van der Meer, F. (2011). Civil Service Systems in Western Europe. Edward Elgar Publishing. doi: https://doi.org/ $10.4337 / 9781781000939$

3. Hoshovska, V. A., Pashko, L. A. (Eds.) (2013). Politychne liderstvo. Kyiv, 300. Available at: http://academy.gov.ua/NMKD/ library_nadu/Navch_Posybniky/a925f1b5-6ad3-4c5c-8199-13dd1aa7ce14.pdf

4. Piren, M. I. (2020). Professional and responsible also historical and legal guidlines for training the civil servants on the success of state building in Ukraine. Bulletin of the National Academy of Public Administration under the President of Ukraine, 2 (97), 111-116. doi: https://doi.org/10.36030/2310-2837-2(97)-2020-111-116

5. Schröter, E., Röber, M. (2015). Verwaltungsausbildung zwischen Tradition und Moderne: Ein dreidimensionales Portrait. Verwaltung \& Management, 21 (3), 125-137. doi: https://doi.org/10.5771/0947-9856-2015-3-125

6. Skills for a high performing civil service (2016). OECD Public Governance Reviews. OECD Publishing, Paris. Available at: https:// www.oecd.org/gov/pem/Skills-Highlights.pdf

7. Marbach, R., Steffens, K., Herr, M., Ziekow, J. (2018). Forming civil servants. Elements of Success and Ideas for Transfer Based on Germany's Dual Public Administration Education. Deutsche Gesellschaft f r Internationale Zusammenarbeit. Available at: https:// www.reformgestaltung.de/fileadmin/user_upload/Dokumente/GIZ_Standard_A4_hoch_en_FOEV_web.pdf 
8. Chechel, A. (2017). Leadership skills as a criteria for assessing the professional competence of heads of departments of the public administration. International Scientific Journal of Universities and Leadership, 4. Available at: https://ul-journal.org/index.php/ journal/article/view/60

9. Krpálek, P., Berková, K., Kubišová, A., Krelová, K. K., Frendlovská, D., Spiesová, D. (2021). Formation of Professional Competences and Soft Skills of Public Administration Employees for Sustainable Professional Development. Sustainability, 13 (10), 5533. doi: https://doi.org/10.3390/su13105533

10. Virtanen, P., Tammeaid, M. (2020). Developing Public Sector Leadership. New Rationale, Best Practices and Tools. Springer, 186. doi: https://doi.org/10.1007/978-3-030-42311-7

11. Gerson, D. (2020). Leadership for a high performing civil service. OECD Working Papers on Public Governance, 40. doi: https:// doi.org/10.1787/ed8235c8-en

12. Bozeman, B. (2000). Technology transfer and public policy: a review of research and theory. Research Policy, 29 (4-5), 627-655. doi: https://doi.org/10.1016/s0048-7333(99)00093-1

13. Klingner, D. E. (2003). Technology Transfer and the Future of Public Administration: An Agenda for Study and Practice. Comparative Technology Transfer and Society, 1 (2), 121-145. doi: https://doi.org/10.1353/ctt.2003.0018

14. Polozhennia pro systemu profesiynoho navchannia derzhavnykh sluzhbovtsiv, holiv mistsevykh derzhavnykh administratsiy, yikh pershykh zastupnykiv ta zastupnykiv, posadovykh osib mistsevoho samovriaduvannia ta deputativ mistsevykh rad vid 6 liutoho 2019 roku No.106-2019-p. Verkhovna Rada of Ukraine. Available at: https://zakon.rada.gov.ua/laws/show/106-2019-\%D0\%BF\#Text

15. Pro vnesennia zmin do statti 20 Zakonu Ukrainy «Pro derzhavnu sluzhbu» shchodo vykliuchennia vymohy vilnoho volodinnia inozemnoiu movoiu dlia derzhavnykh sluzhbovtsiv ta zabezpechennia rivnoho prava dostupu hromadian do derzhavnoi sluzhby: No. 2544 (2019). Uriadovyi portal: Yedynyi veb-portal orhaniv vykonavchoi vlady Ukrainy. Available at: https://www.kmu.gov.ua/ bills/proekt-zakonu-pro-vnesennya-zmin-do-statti-20-zakonu-ukraini-pro-derzhavnu-sluzhbu-shchodo-viklyuchennya-vimogivilnogo-volodinnya-inozemnoyu-movoyu-dlya-derzhavnikh-sluzhbovtsiv-ta-zabezpe

16. Podolchak, N., Khim, M., Tsygylyk, N. (2020). Improving the system of performance evaluation of Ukrainian's civil servants (categories B and C) as one of the factors to improve their professional skills and personal development. Bulletin of the National Academy of Public Administration under the President of Ukraine, 2 (97), 117-128. doi: https://doi.org/10.36030/2310-28372(97)-2020-117-128 